\title{
The Fed and the Real Rate of Interest
}

\author{
G. J. SANTONI and COURTENAY C. STONE
}

\begin{abstract}
"The administration may choose to hide its head, ostrich-like, in the warm sands of economic dogma, but the rest of us must ace the facts. We cannot tolerate these sky-high interest ates - rates that until recenty would have been considered usurious. Congress must act to bring down these killer interest rates before they bring down our economy and the strength and security of our nation."
\end{abstract}

\begin{abstract}
D
URING its last session, which ended on December 23, 1982, the 97th Congress considered several bills that were intended to achieve a "balanced monetary policy." Each bill proposed that the Federal Reserve focus its policy actions on the level of ral interest rates as well as the quantity of money.
\end{abstract}

The Fed was to amnounce publicly its targets for real interest rates, much as it does now with its monetary growth targets. Senate Bill S.2807 specified "yearly targets for positive real [our emplasis] short-term interest rates." One House bill, H. R.6967, emphasized long-term interest rates and required the President of the United States to comment on every monetary policy action. Another House bill, H. R. 7218, required the Federal Reserve to "establish monthly ranges of targets for short-term interest rates, consistent with historical levels of real interest rates [our emphasis]. ..."The initial Sente Concurrent Resolution 128, which was passed in modified form on December 23 , 1982, asked "that the Board of Governors of the Federal Reserve and the Open. Market Committee should take such actions as are necessary to achieve and maintain a level of interest rates low enough to

\footnotetext{
${ }^{1}$ Remarks of Senator Robert C. Byrd, Congressional RecordSenate, August 3, 1982, pp. S9699-700.
}

generate significant economic growth and thereby reduce the current intolerable level of unemployment." Although the resolution does not specify the real rate per se, it is this rate that is relevant for economic growth.

The nominal and real interest rates shown in table 1 are typical of those that have provoked congressional concern. They were part of the supplementary materials accompanying Senate Bill S.2807. In this instance, the real interest rates are derived by subtracting the inflation rate from the various nominal (or market) interest rates for the years shown.

Two aspects of these real rate measures have caused widespread public concern. First, real rates were negatice during certain years in the 1970 s. Since the real interest rate presumably designates the interest rate received after netting out the impact of inflation, negative real rates indicate that individuals who loaned their savings at the nominal rates shown in table 1 ended up poorer as a result; borrowers, on the other hand, increased their wealth by borrowing at negative real rates. Second, and perhaps more politically significant, real rates allegedly have been "sky high" over the past few years. These high rates presumably have retarded economic growth and contributed to lower investment and bigher unemployment. Although the bills that Congress considered differed in certain respects, they shared the same basic notions: that the Federal Reserve an inlluence real rates of interest significantly and that monetary policy should attempt to lower them.

There are several questions that immediately arise when considering the implementation and usefulness of real interest rate targeting for Federal Reserve policy. Which of the host of nominal interest rates should 
Table 1

\section{Nominal and Estimated Real Interest Rates: 1960-82}

\begin{tabular}{|c|c|c|c|c|c|c|c|c|c|c|c|}
\hline & \multicolumn{10}{|c|}{ Interest hates (in percent) } & \multirow{3}{*}{$\begin{array}{l}\text { Inflation } \\
\text { Rate? }\end{array}$} \\
\hline & \multicolumn{2}{|c|}{$\begin{array}{l}\text { Federal } \\
\text { runds Pate }\end{array}$} & \multicolumn{2}{|c|}{$\begin{array}{l}90 \text { dat } \\
\text { T Bul Rate }\end{array}$} & \multicolumn{2}{|c|}{ Prine rate } & \multicolumn{2}{|c|}{$\begin{array}{l}\text { Aaa } \\
\text { Bond hate }\end{array}$} & \multicolumn{2}{|c|}{$\begin{array}{l}\text { New Home } \\
\text { Mortgage Yield }\end{array}$} & \\
\hline & Nomina & near: & Noninal & real? & Nominal & neal & Nomnal & reall & Nomna: & heal & \\
\hline 1960 & 32 & 1,6 & 29 & 13 & 48 & 32 & 44 & 28 & 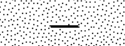 & 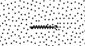 & 16 \\
\hline 1961 & 20 & 11 & 24 & 15 & 45 & 3.6 & 4,4 & 35 & 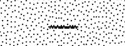 & 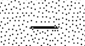 & 09 \\
\hline 9962 & 27 & 00 & 28 & 10 & 45 & 27 & 4.3 & 25 & $\checkmark$ & 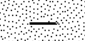 & 18 \\
\hline 1963 & 32 & 17 & 32 & 1,7 & 45 & 30 & 1,3 & 28 & 59 & 44 & 15 \\
\hline 1964 & 35 & 20 & 3.6 & 21 & 45 & 30 & 44 & 29 & 58 & 43 & 16 \\
\hline 1965 & 41 & 10 & 40 & 18 & 45 & 23 & 45 & 23 & 58 & 36 & 22 \\
\hline 1966 & 5. & 19 & 99 & 17 & 56 & 24 & 5.1 & 10 & 63 & 31 & 32 \\
\hline 1967 & 42 & 12 & 4.3 & 13 & 56 & 26. & 5.5 & 25 & 6.5 & 35 & 3.0 \\
\hline 1968 & 5.6 & 12 & 53 & 09 & 6.3 & 18 & 62 & 18 & 70 & 26 & 44 \\
\hline 1969 & 82 & 31 & 67 & 16 & 80 & 29 & 70 & 19 & 78 & 27 & 51 \\
\hline 1970 & 72 & 18 & 6.5 & 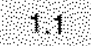 & 79 & 25 & 80 & 26 & 85 & 31 & 54 \\
\hline 1971 & 47 & 0.3 & 44 & 0.6 & 57 & 07 & 74 & 24 & 71 & 27 & 50 \\
\hline 1972 & 44 & 02 & 41 & 0.1 & 53 & 11 & 72 & 30 & 76 & 34 & 42 \\
\hline 1973 & 87 & 29 & 70 & 112 & 80 & 22 & 74 & 16 & 80 & 22 & 5.8 \\
\hline 1974 & 105 & 17 & 79 & -0.9 & 108 & 20 & 86 & 02 & 89 & 01 & 88 \\
\hline 1975 & 5.8 & 3.5 & 58 & 35 & 79 & 4,4 & 88 & 0.5 & 90 & 003 & 93 \\
\hline 1976 & 50 & 02 & 50 & 02 & 68 & 16 & 84 & 32 & 90 & 88 & 52 \\
\hline 1977 & 55 & 0.3 & 53 & 005 & 68 & 10 & 80 & 22 & 90 & 32 & 58 \\
\hline 1978 & 70 & 0.5 & 72 & 0 ? & 91 & 17 & 87 & 13 & 96 & 22 & 74 \\
\hline 1979 & 112 & 2.6 & 100 & 14 & 127 & 41 & 96 & 10 & 108 & 22 & 86 \\
\hline 1980 & 134 & 41 & 115 & 22 & 553 & 60 & 119 & 26 & 127 & 34 & 9.3 \\
\hline 1981 & 164 & 70 & 141 & 47 & 189 & 95 & 14.2 & 48 & 147 & 53 & 94 \\
\hline $1982^{3}$ & 133 & 85 & 115 & 67 & 168 & 110 & 14.4 & 96 & $\mathrm{NA}$ & $\mathrm{NA}$ & 46 \\
\hline
\end{tabular}

The real interest rate shown equals the nominal ate ninus he annual percentage change in he implict price deflator:

Annual percentage change in the implict price deflato:

Through third quarter of 1982

be chosen as the one on which to focus? Which of the wide variety of price indexes should be used to obtain the inflation measure necessary to derive the real rate? What should policymakers do when different real rate measures yield different signals (compare the behavior of the real rate measures in table 1 for 1978 and 1979)? What should policymakers do when their real rate targets conflict with their monetary aggregate growth targets?

Although these questions are interesting, this article does not address them. Instead, the purpose of this article is to show that policy discussions based on real rate estimates derived in the manner shown in table 1 are fundamentally misdirected. First, these estimates are inaccurate. Second, the Fed's impact on them, whatever such measures actually represent, is different from that generally perceived.

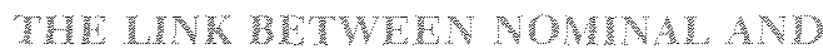

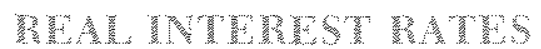

Nominal interest rates quoted in financial markets typically differ from real interest rates. Conceptually, the nominal rate of interest, $i$, can be thought of as the sum of two expected rates of change in value: the expected real rate of interest, $r$ (which indicates the expected rate of change in the value of present goods that are converted into future goods), and the expected rate of inflation, $\dot{\mathrm{P}}_{\mathrm{e}}$ (which is the expected rate of 
Table 2

Average Annual Growth Rates of M1 and Prices and Average Levels of Selected Nominal Interest Rates

\begin{tabular}{|c|c|c|c|}
\hline \% & 195466 & 196782 & Difterence \\
\hline Wh grovith & $247 \%$ & $637 \%$ & $390 \%$ \\
\hline Intation rate & 219 & 6.49 & 430 \\
\hline Aaa corporate bond rate & 406 & 876 & 470 \\
\hline 20 year Treasury securty yeld & 378 & 812 & 434 \\
\hline Conmercal paper rate & 345 & 813 & 468 \\
\hline 90 day Treasury bil rate & 286 & 1720 & 434 \\
\hline
\end{tabular}

change in the value of goods in terms of money). This relationship is shown in equation $1 .{ }^{2}$

(1) $\quad i=1+P$

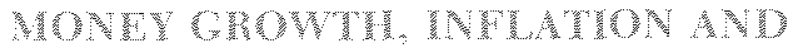

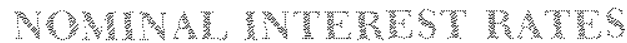

There is no question that monetary policy affects nominal interest rates. As equation i indicates, the expected rate of inflation is a major component of the nominal interest rate. In part this expectation depends upon the expected rate of growth in the money supply. If people should suddenly expect that the Federal Reserve will increase the monetary growth rate permanently, the expected rate of inflation will rise, causing nominal interest rates to rise as well. The reverse holds if individuats should suddenly expect that the Federal Reserve will reduce the monetary growth rate. Thus, over long periods, we would expect that changes in prices and interest rates would be

\footnotetext{
Equation 1 shows the widely ased approximation of the Fisher equation. For an extended discussion, see Irving Fisher, Appreciation and naterest (Augustus M. Kelly, 1965). There are two caveats that should be called to the reader's attention. First, if there are taxes on interest income, the expected real rate in the Fisher equation measires the gross seal rate, not the after-tax net real rate. Second even barring taxes, equation 1 correctly describes the relationship underlyng the nominal interest rate only if the expected rate of intation is held with certanty, i.e., the price level expected in the future is held with certainty. If this is not the case, equation 1 is inaccurate and must be amended by introducing some measure of the "spread" in price expectations. For further discussion, see Levis A. Kochin, The Term Structure of Interest Rates and Cncertain Inflation," (University of Washington. April 1981; processed). Again, we ignore this complexity; for the purpose of our criticism, the expected inflation ate is assuned to be held with certainty.
}

positively associated with movements in money growth. ${ }^{3}$

The data in table 2 are consistent with the proposition that prices, nominal interest rates and money growth move in the same direction over longer time periods. The average growth rate in $\mathrm{Ml}$ increased by about 4 percent between the two long periods shown. Hand in hand with this increase in money growth went higher inflation and higher average levels of nominal interest rates of about the same magnitude.

While monetary growth and the nominal rate of interest are closely related in the long run through the link between monetary growth and expected inflation, it is the short-run link between monetary policy and the real rate of interest that chiefly concerns Congress. The question that naturally arises is, "Why is the real rate of interest of interest?"

\footnotetext{
${ }^{3}$ For some recent studies on the relationship between monev growth and inflation, see Keith M. Garlson, "Money, Inflation and Econonic Growth: Some Updated Reduced Form Results and Their Tmplications," this Revicw (April 1980), bp. 13-19; Keith M. Cartson, "The Lag From Money to Prices," this Review (October 1980), pp. 3-10; John A. Tatom, "Energy l'rices and Short-Ran Econonic Perfornance," this Review (Gantary 1981), pp. 3-17; Dallas S. Batten, "Money Growth Stability and In Hation: An International Comparison," this Revew (October 1981), pp. " Michaef D. Bordo and Ehsar U. Choudhri, "The Link Between Money and Prices in an Open Economy: The Canadian Evidence from 1971-1980." this Reviete (August/September 1982), pp. 13m 23; and Zalman F". Shiffer, "Money and Inflation in Israel: The Transition of an Economy to High Jnflation," this Review (Atugust/ September 1982), pp. 28-40.

${ }^{4}$ For further discassion, see G. J. Santoni and Courtenay C. Stone, "What Realy Happened to Interest Rates? A Longer-Run Analysis," this Review (November 1981), pp. 3-14.
} 
Vy

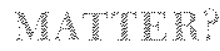

Tochmically, there are several ways in which the real rate of interest can be defined. Looked at one way, the real rate of interest is the net rate of increase in wealth that people expect to achieve when they save and invest their current income. Alternatively, it can be viewed as the expected reduction in wealth that individuals face when they choose to consume goods now instead of saving and investing, in this sense, it represents the relative cost or price of current consumption in terms of foregone future consumption. ${ }^{5}$ As a consequence, the real rate of interest influences the proportion of present resources devoted to producing goods that will be consumed immediately instead of durable goods (capital goods) that will provide consumption goods in the future. The real rate of interest is a relative "price which links one point of time with another point of time."

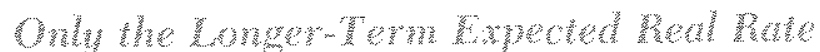

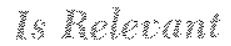

If the purpose of policy is to influence the behavior or actions of individuals, the real interest rate that is relevant is the longer-term expected real rate of interest. "It is easy to see why only the "expected" real rate is important. The actions that people take today are determined by their expectations about the future. ${ }^{8}$ In and of themselves, the consequences of past

\footnotetext{
${ }^{5}$ See, for example, Armen Alchian and William R. Allen, Exchange and Production: Competition, Coordination, and Control Wadsworth Publisbing Co. Inc. 1977), pu. 424-59; One of the first to adopt this view of the interest rate was Galiani who wrote in 1750, as cited in Eugen $Y$. Bohn-Bawerk, Capital and Interest (Kelley and Milman me, 1957), pp. $48-50$, Irving Fisher, The Theory of Interest (Kelley and Milman Inc., 1954), ph. 61, 339; Fricdrich A. Hayek, The Pure Theory of Capital (The University of Chicago Press, 1941), pp. 168-69; Frank Knight, "Capital, Time, and the Interest Rate," Economica (August 1934), pp. 257-86.

${ }^{4} F$ isher, The Theory of Interest, p. 33. See, as well, George J. Stigler, The Theory of Price (The Macmillan Co., 1966), p. 276.

In reality, it is the after-tax, longer-term expected real interest rate that is relevant. We ignore the impact of tixes, because introducing them into the analysis would simply add complexity without affecting the substance of our criticisms of real rate estimations. However, the reader should be wamed that, becatse taxes drive a wedge between the gross real rate and the relevant net-of-tix real rate, their impact must be taken into account if a usefil measure of the expected real rate is to be obtained.

$8^{2}$. . Every act of production is a speculation in the relative value of money and the good produced." Frank Knight, "Unemployment: And Mr. Keynes Revolution in Econonic Thonght, "Canadian Journal of Economics and Political Science, vol. $3(1937)$, p. 113. For a complete treatment, see Fisher, Appreciation and Interest, pp. $1-100$.
}

decisions are irrelevant for current decisionmaking. History cannot be relived, nor can the present consequences of past decisions be undone. While we can learn much from past failures and successes, it is only the information that they provide about potential future outcomes that is relevant for current decisionmaking.

Becalase the distinction between "looking forward" and "looking backward" is so crucial in understanding economic behavior, economists have coined terms to differentiate between them. The relevant interest rate for guiding economic decisions (and the one that this diseassion concerns) is the ex ante real rate-the one that is expected before decisions are made. "The interest rate that is irrelevant for current decisionmaking is the ex post real rate-the one that is obtained by looking back to see what actually occurred. By itself, it is nothing more than a historical datum.

It is equally important to recognize that changes in the longer-term expected real rates have a greater influence on resource use than do shorter-rum, ex ante real rates. In the short run, for a variety of reasons, profitable resource reallocation is more limited or constrained than it is in the long run. Economists characterize this by referring to resource use being fixed in the short run, but variable in the long run. Thus, policy actions must influence the long-rum, ex ante real rate if they are intended to have a significant effect on people's behavior.

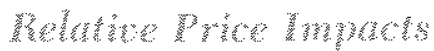

For policymakers concerned with aggregate economic activity, the real rate is particularly important. Since all goods are more or less durable, that is, they yield streams of consumption services that last over varying lengths of time, the real rate of interest influences the relative price or rate of exchange between each good in the economy and every other good. A change in the real rate means that the whole spectrum of prices has changed. ${ }^{10}$

\footnotetext{
ghe rate of interest is always based upon expectation, however little this may be justified by realization. Man makes his gatess of the future and stakes his action upon it . . Our present acts must be controlled by the future not as it actually is, but as it appears to us through the veil of chance. "Irving Fisler, The Rate of Interest The Macmillan Co., 1907), p. 213.

${ }^{10}$ Irving Fisher notes that, "Interest, if not explicitly, will implicity persist, tespite all legal probibitions. It larks in all purchases and sales and is an inextricable part of all contracts." The Theory of Interest, 3.49 . See, as well, pp. 58, 325-81. For further discussion, see Hayek, The Pure Theary of Capital, p. 353; Konght, "Unemployment? And Mr. Keynes's Revolution in Economic Thought," p. 113; Milton Friedman, Price Theory: A Provisional Text Aldine Publishing Co, 1962), pp. 24.5-66.
} 


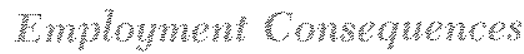

A change in the price of more durable goods relative to less durable goods, which is part and parcel of a change in the real rate, reflects underlying changes in relative demands for all goods and services. These demand shifts will produce significant changes in investment and job opportunities across industries. As a result, total employment may decline following a change in the real rate of interest until labor and resource use have adjusted fully to the new relative demand pattern.

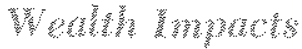

In addition, real interest rate changes produce wideranging wealth changes. To see how this operates, consider an example in which investment opportunities expected to repay $\$ 1.05$ in one year, or $\$ 1.10$ in two years, os $\$ 2.65 \mathrm{~m} 20$ years are each "worth" $\$ 1.00$ today; in each case, the rate of return or "the interest rate" is 5 percent. "If the interest rate suddenly and unexpectedly should rise to 10 percent, the present value of these particulat future claims would all drop. In fact, they would decline in value to about $\$ .96,8.91$ and $\$ .39$, respectively. These are the new amounts that, if invested at 10 percent, would grow to the specified future amounts over the respective time periods.

In other words, increases in the real rate of interest, other things being the same, will reduce the present value of existing claims to future values, even though these future values remain unchanged. This means that unanticipated increases in the real rate of interest will reduce the wealth of all individuals who own such claims, with the more sizable reductions inflicted on those who own the more durable assets (those yielding the longer streams of expected future values). Owners of bonds, stocks, houses, land, etc, lose weat th when the real rate of interest unexpectedly rises.

The opposite occurs when the real rate of interest anexpectedly declines. In this event, people who own durable assets will find that their wealth has increased, with larger percentage increases going to those whose assets are more durable.

\footnotetext{
"The numerical examples use simple anmual compounding - that is, the future amount due in year $t$ is "deflated" by $1 /(1+i)^{t}$ to obtain its "present value." Continuous compounding would profuce only matginal differences in the numbers shown.
}

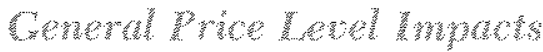

In certain circumstances, an unexpected increase in the real rate of interest directly influences the general price level as well. ${ }^{12}$ Money is a durable good that yields a flow of services over time. Because an unantici pated rise in the real rate reduces the values of durable goods relative to those of nondumable goods, it also can reduce the price of money. Since the price of money is simply the inverse of the general price level, one possible result of an unexpected rise in the real rate is a one-time rise in the general level of prices an increase that some people (but not economists) commonly call a "Burst" of inflation. ${ }^{13}$ Such unanticipated increases in the price level will produce unexpected and seemingly capricious wealth reductions, as well as wealth redistributions among people.

It is not surprising, given these consequences, that changes in real rates of interest are a matter of public concern. These changes produce fluctuations in the aggregate price level, tnexpected changes in people's wealth and sizable impacts on employment and resource use.

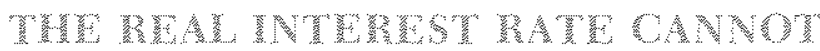

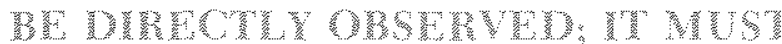

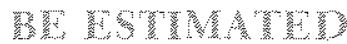

The real rate of interest, a key economic variable, cannot be directly measured or observed. ${ }^{14}$ It is impossible to get exact firsthand knowledge of it.

The problem is that our direct knowledge of interest rates comes from the nominal rates that are deter-

\footnotetext{
${ }^{12}$ The example considered here is one in which there is a general shift in the public's time preferences toward present at the expense of fiture consumption. Other possible shits, for example, an increase in the demand for noney at the expense of other assets or an increase in the investment demand (due to new innovations), colld have different impacts on both the real rate and the general price level than those described in the text.

la The terms "inflation" and "inflation rate" are subject to considerable variation in meaning. People generally take the rate of intlation to mem the rise in some price index between the dates that it is measured. On the other hand, economists often, but not always, refer to inflation as the longer-term trend movement in prices; thus, they distinguish between "the rate of change in the price index" from one period to the rext and "the rate of inllation. "For recent discussion, see Lawrence S. Davidson, "Inflation Misinformation and Monetary Policy," this Review (June/J11y 1982), pp. 15-26. Althongh it grates on our economic sensibilities, we use the "rate of inflation" in its popular (non-economic) sense in the following discussion.

${ }^{14}$ From this point on, the term "ex ante" is deleted to simplify discussion. However, since we intend to analyze interest rates that affect behavior, references to "the rate of interest" refer to the ex ante interest rate inless otherwise noted.
} 
mined in credit markets. As we discussed earlier, these typically are considered to represent the sum of the expected real rate and the expected rate of inflation that credit market participants anticipate for the period of a specific loan. Neither the expected real interest rate nor the expected inflation rate is directly observable-only their sum is a matter of record. When nominal interest rates fluctuate, it is not directly possible to determine whether movements in the ex ante real rate of interest, the expected inflation rate or some combination of both, is responsible. This problem forces researchers and policymakers to confront the issue of measuring the unseen.

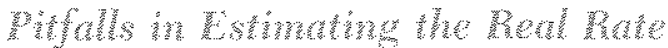

There have been numerous attempts to derive estimates of the expected real rate of interest using the conceptual framework shown in equation 1. The general method of obtaining these estimates involves the following steps: (1) Estimate the unobservable expected inflation rate; (2) Subtract this measure from the observed nominal interest rate; and (3) Label the remainder "the real rate of interest." 15

There is nothing inherently amiss with this procedure: it suggests simply that, in the opinion of the researchers, it is easier and more accurate to first estimate the expected rate of inflation directly, thus deriving estimates of the real rate of interest indirectly. The fruitfulness of this approach can be evaluated only by observing whether the derived estimates of the real rate of interest seem to make sense.

Typically, this procedure uses some weighted average of current and past inflation rates to estimate the current expected inflation rate for future periods. Thus, the procedure involves using an ex post real interest rate measure to estimate the desired ex ante real rate. This will yield accurate results only if the following conditions hold:

\footnotetext{
"Some examples include Albert E. Burger, "An Explanation of Wovements in Short-Tem Interest Rates," this Review Guly 1976), pp. 10-22; John A. Carlson, "Short-Term Interest Rates as Predictors of Inilation: Comment," The American Economic Reviow (June 1977), pp. 469-75; Jan Watter Elliott, "Measuring the Expected Real Rate of Interest: An Exploration of Macroeconomic Alternatives, "The American Economic Review (Jue 1977). pp. 429-44; Eugene F. Fama, "Short-Tern Interest Rates as Predic" tors of Infation." American Economic Review (June 1975) pp. 269-82: Martin Feldstein and Otto Eckstein, "The Fundanental Determinants of the Interest Rate." The Revietw of Economics and Statistics (Novenber 1970), pp. 363-75. Willizm P. Yohe and Denis S. Katrosky, "Interest Rates and Price Level Changes, 1952-1969," this Reviow (Decenter 1969), pp, 18-38
}

\section{Exhibit 1}

Estimating the Real Rate When Only the Expected Happens

\begin{tabular}{|c|c|c|c|c|}
\hline & \multicolumn{4}{|c|}{ Year } \\
\hline & 1 & 2 & 3 & 4 \\
\hline \multicolumn{5}{|l|}{ Beginning of Years: } \\
\hline Expected inflation rate & $10 \%$ & $10 \%$ & $10 \%$ & $10 \%$ \\
\hline Expected real rate & 3 & 3 & 3 & 3 \\
\hline $\begin{array}{l}\text { Nominal fnterest ate } \\
\text { for one-year loans }\end{array}$ & 13 & 13 & 13 & 13 \\
\hline \multicolumn{5}{|l|}{ Measured Intiation Rate; } \\
\hline Durng this year & 10 & 10 & 10 & 10 \\
\hline Durng prevous year & 10 & 10 & 10 & 10 \\
\hline Estimates of Beal Rates. & & & & \\
\hline Nominal nterest rate at & 3 & 3 & 3 & 3 \\
\hline $\begin{array}{l}\text { Nominal interest ate at } \\
\text { begnning of year minus } \\
\text { fast years intlation rate }\end{array}$ & 3 & 3 & 3 & 3 \\
\hline
\end{tabular}

(a) The expected real rate of interest is constant,

(b) Economic policies, in particular monetary policy, are unchanged,

(c) There have been no significant "shocks" or structural changes affecting price levels, that is, no OPEC price changes, no major crop failures or bountiful harvests, etc.

If any of these conditions is violated, the procedure can seriously distort the estimate of expected inflation rate. As a result, estimates of the real rate of interest, derived by subtracting the expected inflation estimates from nominal interest rates, will be distorted as well. ${ }^{16}$

Exhibit 1 depicts a four-year period during which the three conditions listed above are all met. Since there are no ex ante real rate changes or other unexpected "shocks" to price levels, the actual rate of inflation is always equal to the expected rate of inflation. Consequently, estimating the real rate by subtracting

\footnotetext{
${ }^{1+}$ The reader is wamed to read the admonitions that appear in footnotes 2 and 7 . If future price expectations are not held with certainty and if interest meone is taxed, the use of the Fisher equation to derive the real rate will not yidd the relevant real rate of interest.
} 


\section{Exhibit 2}

\section{Unreal Estimates of the Real Rate: When the Unexpected Happens}

\begin{tabular}{|c|c|c|c|c|c|c|c|c|c|}
\hline \multicolumn{5}{|c|}{$\begin{array}{l}\text { Inflation in year } 2 \text { is higher than expected due to } \\
\text { unexpected rise in the exante real rate during year } 2\end{array}$} & \multicolumn{5}{|c|}{$\begin{array}{l}\text { If Inflation in year } 2 \text { is higher than expected due to policy } \\
\text { or supply shocks' which do not affect the ex ante real rate }\end{array}$} \\
\hline & 1 & 2 & 3 & 4 & $\$$ & 1 & 2 & 3 & 4 \\
\hline Beginning of Year: & & & & & Beginning of Year' & & & & \\
\hline Expected nflaton rate & $10 \%$ & $10 \%$ & $10 \%$ & $10 \%$ & $\begin{array}{l}\text { Expected niflaton rate } \\
\text { tor year }\end{array}$ & $10 \%$ & $10 \%$ & $10 \%$ & $10 \%$ \\
\hline $\begin{array}{l}\text { Expected eal rate } \\
\text { for year }\end{array}$ & 3 & 3 & 4 & 4 & $\begin{array}{l}\text { Expected real late } \\
\text { tor year }\end{array}$ & 3 & 3 & 3 & 3 \\
\hline Nominal interest rate & 13 & 13 & 14 & 14 & 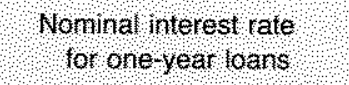 & 13 & 13 & 13 & 13 \\
\hline Measured Inflation Rater & & & & & Neasured Infiation Fate? & & & & \\
\hline During this year & 10 & 15 & 10 & 10 & Durng Ihis year & 10 & 15 & 10 & 10 \\
\hline During prevous year & 10 & 10 & 15 & 10 & During prevrous year & 10 & 10 & 15 & 10 \\
\hline Estimates of Real rates, & & & & & Estimates of Real Rates: & & & & \\
\hline $\begin{array}{l}\text { Nominal nterest rate al } \\
\text { begrning of year ninus } \\
\text { this years intlation rate }\end{array}$ & 3 & 2 & 4 & 4 & $\begin{array}{l}\text { Nominal nierest ate at } \\
\text { beginning of year ninus } \\
\text { this year s niflation ate }\end{array}$ & 3 & & 3 & 3 \\
\hline $\begin{array}{l}\text { Nominal nierest ate at } \\
\text { beginning of Year nirus } \\
\text { last Years hilation rate }\end{array}$ & 3 & 3 & ? & 4 & $\begin{array}{l}\text { Nominal interest rate at: } \\
\text { beginning of year finus } \\
\text { last years nilation rate. }\end{array}$ & 3 & 3 & 2 & 3 \\
\hline
\end{tabular}

either the current or the previous year's inflation rate from the nominal interest rate at the beginning of each year yields identical estimates. Moreover, these estimates are, in fact, equal to the actual (though unobserved) ex ante rate of 3 percent.

Consider, however, what happens when the unexpected occurs; two variations of this are shown in exhibit 2 . The first example shows the impact on real rate estimation over a four-year period when the ex ante real rate unexpectedly rises from 3 percent to 4 percent at some point during the second year. As explained earlier, a rise in the real rate will produce a corresponding rise in current prices; as a result, the rate of inflation during year 2 is greater than was expected at the beginning of the year. Since the price level adjustment to the higher real rate is assumed to have been completed during year 2 (to simplify the analysis), the unusual rise in inflation is not expected to persist. As a result, at the beginning of year 3 , the expected inflation rate remains equal to 10 percent; the nominal interest rate rises to 14 percent to reflect the rise in the real rate.

Notice the difference between the actual ex ante real rate change (from 3 percent at the start of year 2 to 4 percent at the start of year 3 ) and the behavior of the real rate estimates. The first measure suggests that the real rate declined in year 2 ; the second measure depicts a real rate drop in year 3 . Moreover, both measures yield negative real rate estimates, an absurd result for purported estimates of the expected real interest rate. ${ }^{17}$ It is evident that estimates of the real rate obtained using past or current inflation rates are unreliable when the real rate is changing. Not only is the direction of movement likely to be misjadged, but the estimates themselves may tum out to be silly.

Even if the real rate is not changing, typical estimation procedures will yield spurious movements in the purported real rate whenever policy shocks or general economic shocks occur. These shocks will produce episodes during which the actual inflation rate is different from the rate that was expected before the shock. For example, consider case II in exhibit 2 , in which the

\footnotetext{
${ }^{17}$ A number of studies have obtaned negative estimates of the real interest rate. Since we live in a world of productive but scarce resoturces, this is nonsensical, especially for the longer-term real rates. See W. W. Brown and G. J. Santoni, "Unreal Estimates of the Real Rate of Interest, "this Review (January 1981), pp. 18-26. for an explanation that stek results can arise from neasurement errors inherent in curretat price indexes.
} 
real rate is constant but some other event (e.g., an unexpected policy change or an OPEC price increase) produces higher inflation in the second year than is anticipated. Once again, as a comparison between the actual and the different estimates of the real rate indicates, the estimation procedure yields results that are wrong during periods when various shocks are affecting prices in unexpected ways. ${ }^{18}$

In summary, when nothing mexpected happens, the procedure can be used; when the unexpected occurs, as it usually does, the procedure yields strange results over short-run periods.

\section{CHN W Wrates}

As the above analysis indicates, the interpretation of real interest rate estimates is extremely troublesome. This problem has not prevented real rate estimates, however questionable, from affecting policy discussions and debates. Consider, again, the real rate estimates in table 1 that were associated with Senate Bill $\$ .2807$. The negative values alone indicate that they suffer from the estimation problems cited previonsly. Nonetheless, these estimates have captured the attention of the public and policymakers alike.

Therefore, whatever qualms we may have about using these estimates of the real rate. it is clearly of interest to assess the relationship between Federal Reserve actions and changes in these estimates. ${ }^{19}$ First, however, briefly consider the theoretical arguments regarding the relationship between monetary policy and the "true" real rate of interest.

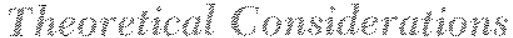

There are two contrasting theoretical arguments concerting the influence of monetary policy on the real rate. Neither of these, however, is consistent with the intent of the bills that Congress was considering.

\footnotetext{
"Of course, additional examples of unreal estimates of the real rate an be obtaned by using some weighted average of past inlation rates instead of a single vear's ate, by lengthening the adjustment time during which poices respond to unanticipated events and by considering the impact of changes in policy that affect the expected rate of inflation. These examples would mercly provide further evidence of the problen with using this approuch to estimating real rates.

${ }^{\text {If }}$ As a practical matter, if the federal Reserve is required to target on the real interest rate, it will, no doubt, link the monetary grow h rate to estimates of the real rate generated by employing a technigue similar to the estimation attempts cited above.
}

One major argument, termed the "neutrality of money doctrine," states that real economic variablessuch as output, employment, economic growth and the real rate of interest -are not influenced permanently by money growth and, therefore, are essentially unaffected by monetary policy. Instead, money growth affects only nominal variables-the price level, the rate of inflation, and nominal interest rates (via the expected rate of inflation). Given this argument, the Federal Reserve has no permanent influence over the real rate of interest whatsoever.

A different theoretical argument, usually called the Mundell effect, states that permanently faster money growth will reduce the real rate of interest, at least temporarily. ${ }^{20}$ This occurs because the permanently higher rate of inflation accompanying accelerated money growth initially reduces people's wealth. As a result of this loss, they decide to save more in an attempt to mitigate the wealth-reducing consequences of higher infation. The increased supply of savings then results in a reduction in the real interest rate.

It is clear that neither of these theoretical arguments support the notion that the Federal Reserve can reduce the real rate of interest in a mamer compatible with the purpose of the congressional bills. If the neutrality argument is valid, the Federal Reserve has no ability to control the real rate of interest at all. Attempts on the part of the Fed to do so would be, at best. ansucessful; at worst, such attempts may be counterproductive to its anti-inflation efforts.

If the "Nundell effect" is valid, the Fed can reduce the real rate only by permanently increasing the rate of inflation and lowering the general level of wealth. Not only is this presumably not the intent of Congress, it directly conficts with those parts of the bills that would make a lower real rate target subordinate to the goal of reducing inflation.

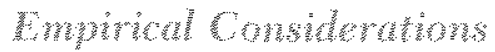

There are several ways to assess the relationship between Federal Reserve actions and estimates of the real rate. Table 3 presents evidence on the correlation between $M 1$ growth and the various estimates of the real rates that appear in table 1 .

Two different correlation comparisons are shown in table 3 . The second column shows the correlation coef-

\footnotetext{
${ }^{20}$ Robert A. Mandell, "Inflation and Real faterest," Journal of Political Economy June 1963), pp. 280-83.
} 
Table 3

Correlation Coefficients for Estimates of the Real Interest Rate and M1 Growth: Annual Data

Estinated faed
Interest rate

1960 to 1981 except for hongage rate $(1963-1981)$

21961 to 1981 except for norgage rate $(1864,1981)$

Table 4

Influence of Monthly M1 Growth on an Aaa Bond Real Interest Rate Measure: February 1951 to November 1982

\begin{tabular}{|c|c|c|c|c|}
\hline & \multicolumn{2}{|c|}{ Februay 195110} & \multicolumn{2}{|c|}{$\begin{array}{l}\text { October } 1979 \text { to } \\
\text { November } 1982\end{array}$} \\
\hline & Coeffolent & 10 & cooficlent & I1 \\
\hline constant & 14885 & 2068 & 10360 & 801 \\
\hline $6_{5}$ & 00088 & 388 & 00840 & 1014 \\
\hline$a$ & 40017 ? & 510 & 03960 & 3,49 \\
\hline$a_{2}$ & 00170 & 423 & $031 / 2$ & 2003 \\
\hline a & 00233 & 542 & 02719 & 1502 \\
\hline$a_{4}$ & +00249 & 553 & 00901 & 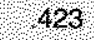 \\
\hline 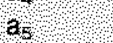 & ४ 00160 & 848 & 00940 & 863 \\
\hline$a_{5}$ & 400292 & ? 631 & 002411 & 1056 \\
\hline$a_{7}$ & 00253 & 556 & 01446 & 666 \\
\hline as & 00000 & $\$ 001$ & ro0036 & 1019 \\
\hline$a_{9}$ & 00074 & 181 & ? 00499 & 301 \\
\hline$a_{10}$ & 00016 & 045 & 401126 & 888 \\
\hline$a_{3}$ & 00025 & 4107 & 40078 & 24 \\
\hline 30 & 00737 & 1221 & 1549 & 926 \\
\hline $\mathrm{n}$ & 9826 & & 8662 & \\
\hline DW & 207 & & 204 & \\
\hline nHol & 127 & 24,536 & 140 & 9.838 \\
\hline F102 & $28^{\prime}$ & 5.410 & 48 & 3,370 \\
\hline $\mathrm{Nob}$ & 344 & & 38 & \\
\hline SEF & 1548 & & 3899 & \\
\hline
\end{tabular}

Significanty different trom zero at he 05 level 
ficients between the levels of the estimated real rates and the growth of $\mathrm{M}$; they range from -.183 to .100 . The third column displays the correlation coefficients between changes in the estimated real rates and changes in the growth of $\mathrm{M} 1$; they range from -.145 to 075 .

Nothing in table 3 demonstrates that the Federal Reserve can infuence these estimates of the real rate by varying the growth of money on a year-to-year basis. Not only are the estimated correlation coefficients small, they are statistically indistinguishable from zero. There is no discemibly significant relationship between either the level of real rates and the growth of Ml or changes in real rates and changes in the growth of $\mathrm{Ml}$. If these real rate estimates actually were indicative of the "true" ex ante real rate, the results in table 3 could be interpreted as supporting the "neutrality of money" hypothesis.

A different test of the Federal Reserve s influence on real interest rate estimates (if not on the real rate itself) can be obtained by looking at the relationship between Ml growth and monthly estimates of the real interest rate. By doing so, we can assess the Federal Reserve's short-run ability to influence estimates of the real interest rate. ${ }^{\mathrm{pl}}$

Table 4 presents the results of assessing the impact of the current and past 11 months' M1 growth on one measure of real interest rates. The specific monthly real interest series used is one that this Bank utilized in the early $1970 \mathrm{~s}$ until it became apparent that the estimates were questionable in the sense discussed earlier. ${ }^{22}$ It is derived by subtracting the average annual rate of change in the seasonally adjusted consumer price index over the prior 36 months from Moody's Index of Aaa bond yields. As constructed, it represents an estimate of long-term expected real interest rates.

\footnotetext{
${ }^{21}$ Becanse there is sone question about the Fed's ability to control M1. growh on a month-to-month basis, the regression relationship in table 4 was estimated using the monetary base growth inplace of $\mathrm{M} 1$ growth. The results were vintually identical. For recent articles ascussing the relationshop between the monetary base and the money stock, see Anatol B. Balbach, "How Controllable Is Money Growth?" this Review (Aprit 1981), pp. 3-12 and R. W. Hafer, "Much Ado About M2," this Rectew October 1981), pp. $13-18$.

${ }^{22}$ This Bank discontinued the use of these estimates in 1975 because the "series suggests that real (interest) rates have fitlen substantially in recent months. There is no supporting evidence that this has happened." Internal memo, Denis S. Karnosky, Research Deparment, Federal Reserve Bank of 5 t. Louts, 1975
}

The relationship in table 4 was estimated over two different time periods, ${ }^{2: 3}$ The first regression estimation assesses the impact of money growth on the monthly real rate series from February 1951 through September 1979. The second estimation assesses the relationship between money growth and the monthly real rate estimate since October 1979 , the month in which the Fed announced that it would focus more attention on money growth in implementing monetary policy. The two periods were analyzed separately to determine whether the Federal Reserve's action on October 6, 1979, has resulted in any significant change in the relationship between money growth and these estimates of the real interest rate.

The results shown for the February 1951 to September 1979 period indicate that current and lagged money growth have no discernible effect on the real interest rate measure. While the $\overline{\mathrm{R}}^{2}$, which measures the proportion of the variation in the real rate "explained" by the regression equation (adjusted for the number of regressors used), is close to one, the "explanatory power" of the equation is derived from the rho coefficients that adjust for the existence of first-and second-order autocortelation and from the constant term. None of the individual coefficients on M1 growth (which range from - -00249 to .00292 ) differs statistically from zero. Moreover, the sum of the coefficients on MI growth, which is an estimate of the net impact of money growth over a 12 month period, is not statistically different from zero. Thus, during this period, the real rate was not affected discernibly by short-run money growth.

The second set of estimates, for the period since October 1979 , yields results that are virtually identical to those from the earlier period. The "explanatory power" of the estimated equation is derived chiefly from the autocorrelation coefficients alone: the constant term is not statistically different from zero. Once again, money growth has essentially no effect on the reat rate of interest. Although $a_{1}$, the coefficient that measures the impact of last month's money growth on this month's real interest rate is statistically signifcant-and positive at that-the sum of the money growth coefficients is not significantly different from zero. There is no net impact of shortmun money growth on the real rate.

\footnotetext{
2athe procedure used was generalized-least-squares regression. The eqtation was estimated correcting for first-order and secondorder antocorrekation using a maximum-likelihood grid search procedure.
} 
The overall impression that emerges from the results shown in table 4 is that the federal Reserve is unkely to be able to influence mon th-to-month movements in estimates of the real interest rate by varying money growth over short-run periods. ${ }^{24}$ Money

2the results reported here are simitar to those derived recently from two alternative approaches to assessing the inpact of monetary policy on quarterly real interest rates. R. W. Hafer and Seott E. Hein, in "Monetary Policy and Short-Term Real Rates of Interest, "this Review (March 1982). pp. 13-19, looked at the relationship between guartenly estimates of the expost real threemonth Treasury bill rate and current and lagged levels of the "real" money stock (mensured by the "real" monetary base). They found that an increase in the real money stock reduced their real rate measure in the same quarter but rased in in the next quarter by virtually the same anount with no sebseguent impact. Thus, they condude "there is no evidence of a long-run effect ruming from changes in real money balanees to changes in real interest rates."

Keith M. Carlson, in "The Mix of Monetary and Fisal Policies: Conventional Wisdon Vs. Empirical Reality, "this Reciew (October 1982 , pp. $7-21$, finds that in general "monetary and fiscal actions do little to explain the movement of the real rate als measured by the Aaa bond rate minus intlation." When he assessed the impact of current and latged growth in Ml (ap to 20 -quarter lags) on quarterly estinates of the Aat real rate, he found that the monetary growth coefficients were positice and significant for the period from I/ 1959 to IV/1981; however, the $\overrightarrow{\mathrm{F}}^{2}$ was small (from .04 to .06). As Carlson notes, the positive relationship "should probably not be taken too seriously, however. becare of the problems inherent in measuring the real rate." growth had no significant impact on these estimates prior to October 1979 and has had virtually none since then.

\section{K)}

The expected real rate of interest is an important economic variable that, although directy unobseryable, has a pervasive influence on the allocation of resources and on the distribution of weath. Whether the Federal Reserve can control or influence the actual real rate is an unsettled issue. What is clear, however, is that discussions about the real rate and the Fed's influence on it have been misdirected. Because the most commonly used estimates of the real rate are subject to substantial emors, it would be a serious mistake to base policy actions on them.

In addition, the Federal Reserve cannot affect estimates of the real interest rate, whatever their validity. Thus, the passage of any bill requiring the Fed to set policy on the basis of real rate estimates would inevitably send it in pursuit of some monetary will-o-thewisp.

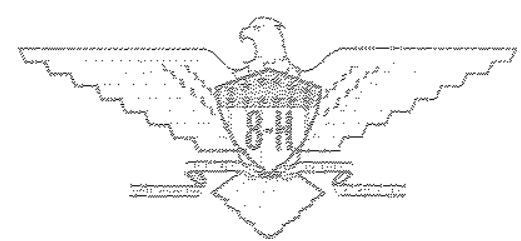

